\title{
Correction: A 74-year-old woman with dyspnoea and a mass in the right atrium
}

Rijlaarsdam MA, van Boven WJ, Planken RN, et al. A 74-year-old woman with dyspnoea and a mass in the right atrium. BMJ Case Reports 2018; doi:10.1136/bcr-2017-222261.

In the published paper, the correct figure 4 should have been:

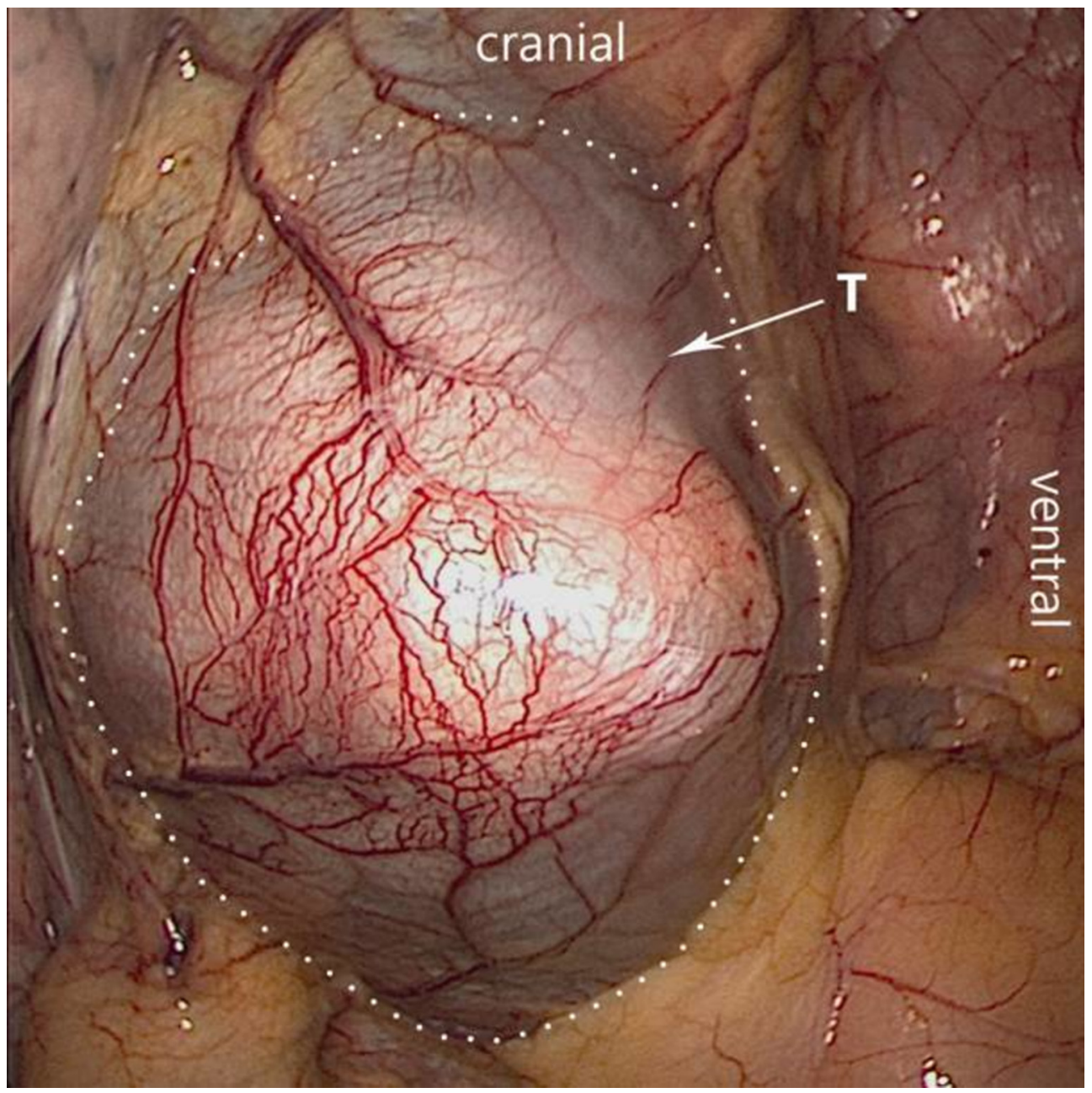

Furthermore, the acknowledgement section was missing; it should have been as follows:

The authors would like to thank our colleagues in the Academic Medical Centre, Amsterdam (NL) for their support in describing the clinical course and the various diagnostic modalities/ images: W.E.M. Kok MD PhD (department of cardiology), S.M. Boekholdt MD PhD (department of cardiology), R. Britstra MD PhD (department of Pathology) and A.H.G. Driessen MD $\mathrm{PhD}$ (department of cardio-thoracic surgery). We thank our colleagues from the Rode Kruis Hospital, Beverwijk (NL) for providing details about the initial presentation and management of this patient (M.A.C. Koole MD \& R. Kist MPA).

(C) BMJ Publishing Group Ltd (unless otherwise stated in the text of the article) 2018. All rights reserved. No commercial use is permitted unless otherwise expressly granted.

BMJ Case Rep 2018. doi:10.1136/bcr-2017-222261corr1

A) Check for updates 
Copyright 2018 BMJ Publishing Group. All rights reserved. For permission to reuse any of this content visit http://group.bmj.com/group/rights-licensing/permissions.

BMJ Case Report Fellows may re-use this article for personal use and teaching without any further permission.

Become a Fellow of BMJ Case Reports today and you can:

- Submit as many cases as you like

- Enjoy fast sympathetic peer review and rapid publication of accepted articles

Access all the published articles

- Re-use any of the published material for personal use and teaching without further permission

For information on Institutional Fellowships contact consortiasales@bmjgroup.com

Visit casereports.bmj.com for more articles like this and to become a Fellow 